\title{
Intravesical sodium hyaluronate reduces severity, frequency and improves quality of life in recurrent UTI
}

\author{
Deepak Batura $^{1}\left[\right.$ D $\cdot$ Roisin Warden ${ }^{2} \cdot$ Tumaj Hashemzehi $^{1} \cdot$ Malwina Julia Figaszewska ${ }^{1}$
}

Received: 9 August 2019 / Accepted: 3 October 2019 / Published online: 15 October 2019

(c) The Author(s) 2019, corrected publication 2019

\begin{abstract}
Purpose Urinary tract infections (UTI) occur in nearly half of all women at least once, with around 35\% experiencing recurrences. Bladder mucosal glycosaminoglycan (GAG) layer damage is postulated to contribute. Sodium hyaluronate (SH) replenishes the GAG layer and is believed to be protective. However, there is limited literature on patient-reported outcomes and quality of life (QoL) after treatment. Our objective was to observe changes in UTI severity and QoL after treatment with intravesical SH.

Methods In this retrospective, observational patient-reported outcome study, we examined outcomes in UTI patients treated with intravesical SH. SH was instilled weekly for 6 weeks. If symptoms persisted, patients received further instillations on demand. Patients were sent postal questionnaires to score symptoms before and after treatment. Patient-reported UTI occurrences before treatment were compared with recurrences after treatment collected from their primary care providers. Results There were 18 (58.1\%) valid replies. The median age was 75 . The median duration of illness before treatment was 4.5 (IQR 2.8-7) years. The median number of infections fell from ten per year (IQR 7-10) before treatment to two per year (IQR 0-5) after treatment. Pain improved by $34 \%$, urgency 30\%, nocturia $30 \%$, frequency $32 \%$, 'inability to carry out daily activities due to UTI related ill-health' $37 \%$ and 'loss of sleep' by $38 \%$. Patients reported a $76 \%$ improvement in 'UTI-related QoL.' No adverse events were reported.

Conclusion SH is safe and useful for managing patients with recurrent UTI, with improvements in symptoms, QoL, a decrease in the number of UTI episodes and in the best interests of antimicrobial stewardship.
\end{abstract}

Keywords Urinary tract infections $\cdot$ Hyaluronic acid $\cdot$ Sodium hyaluronate $\cdot$ Intravesical administration $\cdot$ Patient-related outcome measures · Quality of life · Antimicrobial stewardship

\section{Introduction}

Urinary tract infections (UTI) are widespread. It is estimated that more than 150 million people are affected every year, with over 10.5 million UTI-related office visits in the USA in 2007 [1, 2]. Recurrent urinary infections are defined in

Data from this study were presented at the 37 th Congress of the Societe Internationale d'Urologie in Lisbon, Portugal on 22 Oct 2017.

Deepak Batura

deepakbatura@gmail.com

1 Department of Urology, London North West University Healthcare NHS Trust, Watford Road, London HA1 3UJ, UK

2 Department of Urology, Imperial College Healthcare NHS Trust South, Wharf Road, London W2 1BL, UK the European Association of Urology (EAU) guidelines as two or more episodes of lower UTI in the last 6 months, or three or more episodes of lower urinary tract infection in the last 12 months [3]. UTI occurs in nearly half of all women at least once in their lifetime, with around 35\% experiencing recurrences within 6 months $[4,5]$. The average recurrence rate has been estimated to be 2.6 infections per year [4]. Apart from the morbidity and effect on an individual's quality of life (QoL), the economic burden of UTI is considerable ( $\$ 2.8$ billion due to UTI hospitalisations in the USA in 2011 and $€ 58$ million societal costs in France in 2012-2013) $[6,7]$. Besides the fiscal impact, the frequent use of antimicrobials in these patients contributes to the worrisome trend of increasing antimicrobial resistance as well as the morbidity caused by adverse drug effects. Not surprisingly, several therapeutic agents beyond antimicrobials are being trialled for treating recurrent UTI, although with mixed success [8]. 
One such treatment is intravesical administration of a solution of sodium hyaluronate $(\mathrm{SH})$.

Sodium hyaluronate is the sodium compound of glycosaminoglycan-hyaluronic acid. Hyaluronic acid is a viscous polymer of disaccharide units of Na-glucuronate- $\mathrm{N}$-acetylglucosamine. Hyaluronic acid is a ubiquitous constituent of the extracellular matrix, and functions in healthy tissues to regulate cell growth, differentiation and to inhibit inflammation [9]. Because of its viscosity and elasticity, it serves as a natural lubricant and tissue-protective agent. The compound finds use in orthopaedics as an intraarticular agent for the treatment of osteoarthritis, and in various ophthalmic conditions as an intraocular injection and as topical drops. Its other applications include its use to promote wound healing and in cosmetic procedures as a dermal filler. More recently, it has found use in nanocarrier delivery systems for administering cancer chemotherapy.

The rationale for the use of SH in UTI is that infection causes damage and depletion of the bladder mucosal glycosaminoglycan (GAG) layer and $\mathrm{SH}$ forms a protective coating, helping to shield the epithelium from whole bacteria and flagellin proteins. The putative mechanisms include SH functioning as a barrier to protect the urothelium from bacterial adherence and also by augmenting the immune response of the epithelium to bacterial virulence factors [10]. At present, there are no National Institute for Health and Care Excellence (NICE), British Association of Urological Surgeons (BAUS) or American Urological Association (AUA) guidelines available on SH. The EAU guidelines mention $\mathrm{SH}$ as a valuable and beneficial agent, though acknowledging that the evidence in favour of its use is low-powered and that more research is needed [3]. Currently, there is limited literature describing patient-reported outcomes and QoL after treatment with intravesical SH, and studies examining these aspects of care are needed to help define the role of $\mathrm{SH}$ as a treatment option [8].

The objectives of this study were to assess for changes in UTI severity, frequency and QoL in patients with recurrent UTI after treatment with intravesical SH.

\section{Patients and methods}

In this retrospective, observational patient-reported outcome study, we investigated patients who were treated for recurrent UTI with SH. The inclusion criteria were patients who had had recurrent UTI as defined by the EAU guidelines and who had failed standard preventive strategies as well as prior treatment with multiple courses of antimicrobials, oral D-mannose, pentosan polysulphate sodium, cranberry and topical oestrogen therapy (where atrophic vaginitis coexisted with UTI). The exclusion criteria were UTI with indwelling catheters, haematuria, pneumaturia or fecaluria, urolithiasis, developmental anatomical anomalies neurogenic bladders, persistent Proteus infections and pregnancy. We also excluded patients with residual bladder urines over $200 \mathrm{ml}$ and those that had asymptomatic bacteriuria. We used the United Kingdom Home Office self-declared ethnicity codes to collate patient ethnic backgrounds.

Initially, $40 \mathrm{mg} / 50 \mathrm{ml}$ of SH was instilled into the bladder weekly for 6 weeks. Later, we switched to $120 \mathrm{mg} / 50 \mathrm{ml}$ for induction as we perceived that the higher dose was more efficacious than $40 \mathrm{mg} / 50 \mathrm{ml}$. If symptoms persisted or recurred, patients also received instillations with $120 \mathrm{mg} / 50 \mathrm{ml} \mathrm{SH}$ on-demand on self-perceived relapses, after confirming that there were no other underlying causes for the recurrence of symptoms. One patient had SH using Cystistat $^{\circledR}$ (Teva UK Ltd, Harlow, UK); all the others were treated with Hyacyst ${ }^{\circledR}$ (Syner-Med Pharmaceutical Products Ltd, Purley, UK). All instillations were carried out by a qualified Urology nurse practitioner in an outpatient setting. No peri-procedure antimicrobial agents were given at instillations.

At the end of treatment, questionnaires were sent by mail to all consecutive consenting patients who had been treated with $\mathrm{SH}$, to enable the collection of patient-reported outcome score of symptoms, UTI occurrences and antibiotic usage before treatment. The self-reported UTI episodes were based both on self-perception as well as from patients' visits to their GPs for treatment. As these events were self-reported by laypeople, a strict definition of UTI was not employed. As symptoms occur intermittently with different intensity though various UTI episodes in such patients, we have attempted to capture general symptoms as against event-specific symptoms to assess the overall change in the domains of distress and quality of life. Symptoms after treatment were self-reported as well. All symptoms were self-scored on a Likert scale and pain was recorded on the British Pain Society rating scale $[11,12]$. The questionnaires were in English language and were sent out after telephonic consent and with a self-addressed stamped envelope to facilitate return. One reminder letter with a self-addressed stamped envelope was sent out to delayed responders. No financial or other incentives were offered to participants to facilitate a response.

Clinical notes and hospital computer-based clinical information systems were used to collect patient demographic information such as presenting clinical features, age, sex and ethnicity. Additional demographic details such as the number of births as well as UTI recurrences and antibiotic usage after treatment were collected telephonically from the patients' primary care providers. Discrete variables were reported to the nearest integer. Standard descriptive statistical tests were employed. The 2-tailed student $T$ test with unequal variance was used to calculate the difference between means. Significance was set at the 0.05 level. 
As recommended by the National Research Authority, England, ethical approval was not sought as the study was a retrospective analysis of routinely collected anonymised laboratory and hospital data.

\section{Results}

We sent out survey instruments to 31 UTI patients and received valid responses from $18(58.1 \%)$. There were no discernible differences in trends between the responders and non-responders concerning their ages, co-morbidities and ethnicities.

All the 18 patients were women, and their median age was 75 (IQR 42.5-81) years. Thirteen patients were white, four were Asian/Asian British, and one was of mixed ethnicity. Four patients had diabetes and one was currently using methotrexate and prednisolone for rheumatoid arthritis, which could have altered their immune status. The remaining patients did not have any factors that may have predisposed them to have a recurrence of UTI, including prior radiation therapy to the pelvis or any systemic chemotherapy. With regards to their obstetric history, four patients had never given birth, six had one birth, four had two, I had three births and obstetric history was not available or disclosed in one patient. All the births were by normal delivery, except for one which was via an uncomplicated caesarean section. The median number of births in our patients was 1 (IQR 1-2). These details are reported in Table 1.

Table 1 Patient characteristics and frequency of infections before and after treatment

\begin{tabular}{|c|c|c|c|c|c|c|c|c|c|}
\hline No. & Age (years) & Ethnicity & $\mathrm{DM}$ & $\begin{array}{l}\text { Immune alter- } \\
\text { ers }\end{array}$ & Births & $\begin{array}{l}\text { Disease dura- } \\
\text { tion (years) }\end{array}$ & Protocol & $\begin{array}{l}\text { UTI/year } \\
\text { before } \\
\text { treatment }{ }^{\mathrm{a}}\end{array}$ & $\begin{array}{l}\text { UTI/ } \\
\text { year after } \\
\text { treatment }^{\mathrm{b}}\end{array}$ \\
\hline 1 & 74 & White & Yes & No & 1 & 2013-2017 & $40 \mathrm{mg} \times 6$ & $\geq 10$ & 0 \\
\hline 2 & 55 & White & Yes & No & $1^{\mathrm{c}}$ & 2014-2016 & $40 \mathrm{mg} \times 4$ & $\geq 10$ & 2 \\
\hline 3 & 19 & White & No & No & 0 & 1998-2016 & $40 \mathrm{mg} \times 6$ & $\geq 10$ & 2 \\
\hline 4 & 40 & $\begin{array}{l}\text { Asian/Asian } \\
\text { British }\end{array}$ & No & No & 3 & 2000-2017 & $40 \mathrm{mg} \times 6$ & $\geq 10$ & 3 \\
\hline 5 & 94 & White & No & No & 2 & 2015-2016 & $40 \mathrm{mg} \times 6$ & Unsure & 3 \\
\hline 6 & 81 & White & Yes & No & 1 & 2014-2016 & $\begin{array}{l}40 \mathrm{mg} \times 1 \\
120 \mathrm{mg} \times 6\end{array}$ & $\geq 10$ & 0 \\
\hline 7 & 90 & White & No & No & 1 & 2012-2016 & $120 \mathrm{mg} \times 14$ & $\geq 10$ & 6 \\
\hline 8 & 72 & White & No & $\begin{array}{l}\text { Methotrexate } \\
\text { and predni- } \\
\text { solone }\end{array}$ & 0 & 2013-2017 & $120 \mathrm{mg} \times 12$ & Unsure & 0 \\
\hline 9 & 40 & $\begin{array}{l}\text { Asian/Asian } \\
\text { British }\end{array}$ & No & No & 0 & 2015-2018 & $40 \mathrm{mg} \times 1$ & Unsure & 0 \\
\hline 10 & 76 & White & No & No & 2 & 2014-2017 & $\begin{array}{l}40 \mathrm{mg} \times 3 \\
120 \mathrm{mg} \times 6\end{array}$ & 8 & 8 \\
\hline 11 & 76 & White & No & No & 4 & 2014-2017 & $40 \mathrm{mg} \times 13$ & Unsure & 0 \\
\hline 12 & 29 & Mixed & Yes & No & 0 & 2014-2015 & $\begin{array}{l}40 \mathrm{mg} \times 6 \\
120 \mathrm{mg} \times 6\end{array}$ & 8 & 5 \\
\hline 13 & 82 & White & No & No & 1 & 2014-2015 & $\begin{array}{l}40 \mathrm{mg} \times 6 \\
120 \mathrm{mg} \times 1\end{array}$ & 6 & 8 \\
\hline 14 & 85 & White & No & No & 1 & 2014-2015 & $\begin{array}{l}40 \mathrm{mg} \times 2 \\
120 \mathrm{mg} \times 11\end{array}$ & 6 & 1 \\
\hline 15 & 81 & White & No & No & 2 & 2010-2018 & $40 \mathrm{mg} \times 6$ & 4 & 0 \\
\hline 16 & 54 & $\begin{array}{l}\text { Asian/Asian } \\
\text { British }\end{array}$ & No & No & Not disclosed & 2011-2018 & $\begin{array}{l}40 \mathrm{mg} \times 6 \\
120 \mathrm{mg} \times 6\end{array}$ & $\geq 10$ & $\geq 10$ \\
\hline 17 & 40 & $\begin{array}{l}\text { Asian/Asian } \\
\text { British }\end{array}$ & No & No & 4 & 2012-2018 & $120 \mathrm{mg} \times 4$ & 6 & 1 \\
\hline 18 & 50 & White & No & No & 2 & 2012-2016 & $40 \mathrm{mg} \times 18$ & Unsure & 0 \\
\hline Median & $\begin{array}{l}75 \text { (IQR } \\
42.5-81)\end{array}$ & & & & 1 (IQR 1-2) & $\begin{array}{c}4.5 \text { (IQR } \\
2.8-7)\end{array}$ & 8 (IQR 6-12) & 10 (IQR 7-10) & 2 (IQR 0-5) \\
\hline
\end{tabular}

${ }^{\mathrm{a}}$ Based on patient recall

${ }^{\mathrm{b}}$ Given by patient's primary care provider

${ }^{\mathrm{c}}$ By caesarean section 
All urine samples were examined by microscopy and were cultured on CLED and chromogenic agar (Oxoid, Basingstoke, UK) at $37^{\circ} \mathrm{C}$ in air for $18-24 \mathrm{~h}$. A colony count of $>100,000 \mathrm{cfu} / \mathrm{ml}$ was considered as significant. Antibiotic sensitivities were performed using the BSACS method [13]. Positive urine cultures immediately proximate to the commencement of SH treatment showed that $E$. coli was the most common organism with eight patients growing $E$. coli in their urine, of which one was an extended spectrum beta-lactamase (ESBL) producer. Two patients grew Enterococcus species in their urine and in three the growth was reported as "coliforms" and not further qualified. There were five patients with a heavy mixed growth of organisms. Except for the ESBL E. coli, all the others were sensitive to

Table 2 Mean of symptoms scores before and after intravesical sodium hyaluronate treatment

\begin{tabular}{llllll}
\hline $\begin{array}{l}\text { Means of } \\
\text { scores }\end{array}$ & Before & After & $\begin{array}{l}\text { Mean differ- } \\
\text { ence (SD, } \\
\text { CI) }\end{array}$ & difference & $p$ value \\
\hline Pain & 7.2 & 4.8 & $2.5(3.4,1.6)$ & 34 & 0.034 \\
Frequency & 8.1 & 5.5 & $2.6(3.3,1.5)$ & 32 & 0.008 \\
Nocturia & 8.1 & 5.6 & $2.4(3.5,1.6)$ & 30 & 0.018 \\
Urgency & 7.3 & 5.1 & $2.2(3.7 .1 .8)$ & 30 & 0.066 \\
Loss of sleep & 7.4 & 4.6 & $2.8(3.6,1.7)$ & 38 & 0.024 \\
Loss of activ- & 5.4 & 3.5 & $2.0(3.1,1.8)$ & 37 & 0.196 \\
$\quad$ ity & & & & & 0.056 \\
QoL & 2.6 & 4.6 & $2.0(3.3,1.6)$ & 76 & \\
\hline
\end{tabular}

Symptoms were scored from $1=$ least severe to $10=$ most severe. Quality of life was scored from $1=$ worst to $10=$ best cephalosporins. Two colonies were resistant to amoxicillin and one to trimethoprim.

The median duration of recurrent UTI before treatment was 4.5 (IQR 2.8-7) years. The median number of infections per year before and after treatment is shown in Table 1 . The median number of infections fell from ten per year (IQR 7-10) before treatment to two per year (IQR 0-5) after treatment. 17/18 patients had a decrease in the frequency of UTI. Patients had a median number of 8 (IQR 6-12) instillations of SH. Nine patients were treated exclusively with the $40 \mathrm{mg} / 50 \mathrm{ml}$, three with the $120 \mathrm{mg} / 50 \mathrm{ml}$ and six with an induction dose of $40 \mathrm{mg}$ and a "top-up" on-demand dose of $120 \mathrm{mg}$. Our cohort was followed up from the date of the first SH instillation until April 2019. The median follow-up period was 62 (IQR 56-71) months.

The changes in symptom scores and quality of life domains before and after SH treatment are reported in Table 2 and shown in Fig. 1. In our patients, improvement in the mean pain score was 2.5 (34\%) (SD 3.4, CI 1.6), urgency 2.2 (30\%) (SD 3.7, CI 1.8), 'nocturia' 2.4 (30\%) (SD 3.5, CI 1.6), 'frequency' 2.6 (32\%) (SD 3.3, CI 1.5), 'inability to carry out daily activities to UTI related ill-health' 2.0 (37\%) (SD 3.1, CI 1.8) and 'loss of sleep' by 2.8 (38\%) (SD 3.6, CI 1.7). Except for 'urgency' and 'inability to carry out daily activities' fields, the differences in the mean scores of symptoms before and after SH instillations were significant. Although just failing to reach statistical significance at 0.05 , there was an improvement in QoL by $76 \%$ after SH instillations. We did not note any association between dosages used and outcomes. No adverse events occurred during or after treatment, though most patients reported a burning discomfort during and immediately after instillations.
Fig. 1 Mean of symptoms scores before and after intravesical sodium hyaluronate treatment

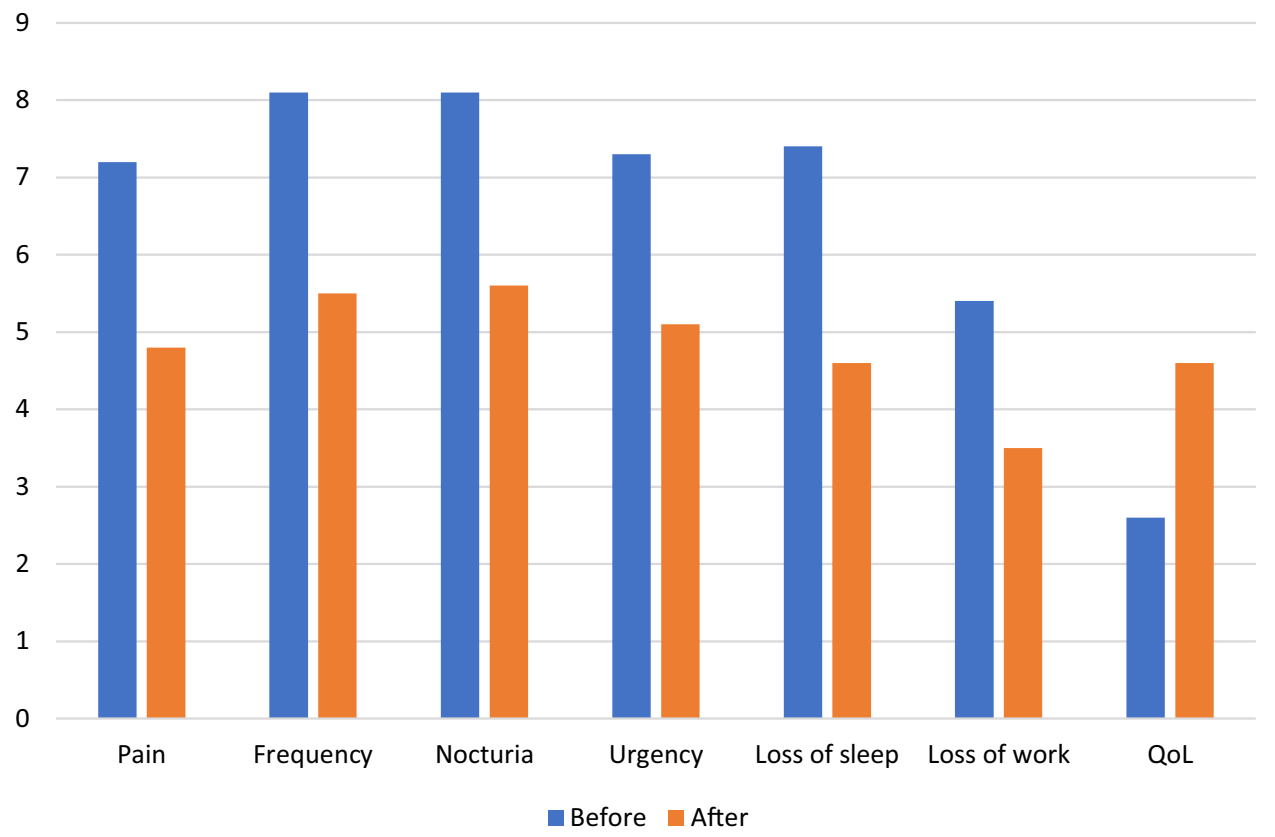




\section{Discussion}

In this paper, we have shown that intravesical SH is a safe alternative strategy to manage recurrent UTI that does not depend on regular or suppressant antimicrobial usage. In our patients, SH led to a decrease in the frequency of UTI. We have also shown that patients reported a decrease in the severity of infection-related symptoms like urgency, nocturia and frequency after they were treated with SH. Benefits included better sleep and a decrease in activity lost due to UTI-related ill-health following treatment. Unsurprisingly, therefore, patients reported a significant improvement in their quality of life as well.

The response rate from our patients to the survey instrument was about 58\%. This rate is within the expected range from patient populations who have been asked to respond to similar self-administered surveys [14].

With a realisation of the role of the GAG layer in providing a barrier towards preventing recurrence of UTI, there has been an increasing interest in exploiting this natural mucosal defence for preventing and diminishing the rate and severity of recurrent UTI. There is now a growing body of evidence testifying to the benefit of $\mathrm{SH}$ in the treatment and prevention of recurrent UTI. In a pilot study, Constantinides et al. reported that $70 \%(28 / 40)$ of their patients were recurrence free after a 15.8 -month follow-up, with a decrease in the mean annual rate of UTI and an increase in recurrence-free intervals, although their cohort was younger than in the present study (mean age 35 years), and they used only Cystistat in a lower dose and with a different instillation frequency [15]. Other studies have reported outcomes with recurrence-free rates ranging from $53 \%(7 / 13)$ to $64 \%(14 / 22)$ infection-free rates at the end of at least one-year follow-up, or a significant decrease in the number of annual recurrences from 4.99 to 0.56 [16-18]. In addition, some studies have investigated the action of a combination of SH with chondroitin sulphate. Some of these studies have been more extensive and have included two randomised trials as well. All these studies have demonstrated a reduction in the mean number of UTI recurrences and an increase in the recurrence-free interval [19-22]. Thus, our results have been congruent with the outcomes reported in the literature.

SH instillations are costly and labour intensive [23, 24]. However, these costs need to be weighed against the costs of antimicrobial resistance and the costs of treatment of adverse side effects of antimicrobials in patients. Thus, $\mathrm{SH}$ bladder instillations to manage recurrent UTI are in the best interests of antimicrobial stewardship by decreasing the overuse of antibiotics.

Our study has some strengths. To the best of our knowledge, this is the first study to examine patient-reported outcomes and changes in quality of life (QoL) occurring as a result of SH use in the treatment of recurrent UTI. Moreover, although we have used patient-reported metrics for data before treatment, we have gathered most data of outcomes after treatment from the patients' primary care providers, as these data are not subjective or patient perceived, and hence reduce the element of recall. The study also has some limitations. Firstly, it is retrospective. Furthermore, patient-reported outcomes such as those we have reported are dependent on accurate recall and are subjective. We have also not carried out any bacterial correlations with symptoms as we note that UTI symptoms and distress are not dependent on the nature of the microorganism and reflect the severity of the condition irrespective of the organism cultured. We have not been able to reliably collect information on other medications our patients were using during the study period that may have had an effect on bladder function, such as diuretics, antimuscarinic agents or antidepressants and antipsychotics. Our study comprised of a modest number of patients although most previous studies on SH have been small in size as well. Furthermore, the dosage regimens have not been consistent making it difficult to predict factors or covariates of a favourable response to $\mathrm{SH}$.

\section{Conclusion}

We conclude that intravesical SH is safe and useful in the management of patients with recurrent UTI, with improvements in symptoms scores, pain, QoL and a decrease in the number of repeat UTI episodes. Further studies with a larger number of patients are warranted to understand better how to optimise the utility of SH in the management of recurrent UTI, the best dosing schedule and the ideal strength.

\section{Compliance with ethical standards}

Conflict of interest D Batura has received speakers' honoraria from Astellas and conference support from Syner-Med \& Speciality European Pharma between 2013 and 2017. The other authors have no conflicts of interest.

Ethical approval All procedures performed were in accordance with the ethical standards of the institutional and with the 1964 Helsinki declaration and its later amendments or comparable ethical standards. This article does not contain any studies with animals performed by any of the authors.

Open Access This article is distributed under the terms of the Creative Commons Attribution-NonCommercial 4.0 International License (http://creativecommons.org/licenses/by-nc/4.0/), which permits any noncommercial use, distribution, and reproduction in any medium, provided you give appropriate credit to the original author(s) and the source, provide a link to the Creative Commons license, and indicate if changes were made. 


\section{References}

1. Harding GKM, Ronald AR (1994) The management of urinary infections: what have we learned in the past decade. Int J Antimicrob Agents 4:83-88

2. Flores-Mireles AL, Walker JN, Caparon M, Hultgren SJ (2015) Urinary tract infections: epidemiology, mechanisms of infection and treatment options. Nat Rev Microbiol 13:269-284

3. Bonkat G, Bartoletti RR, Bruyère F, Cai T, Geerlings SE, Köves B, Schubert S, Wagenlehner F, Mezei T, Pilatz A, Pradere B, Veeratterapillay R (2019) Guidelines on urological infections. Retrieved from http://uroweb.org/guideline/urological-infections /\#3. Accessed 11 Oct 2019

4. Foxman B (2002) Epidemiology of urinary tract infections: incidence, morbidity, and economic costs. Am J Med 113:5s-13s

5. Mabeck CE (1972) Treatment of uncomplicated urinary tract infection in non-pregnant women. Postgrad Med J 48:69-75

6. Simmering JE, Tang F, Cavanaugh JE, Polgreen LA, Polgreen PM (2017) The increase in hospitalizations for urinary tract infections and the associated costs in the United States, 1998-2011. Open Forum Infect Dis 4:ofw281

7. François M, Hanslik T, Dervaux B, Le Strat Y, Souty C, Vaux S, Maugat S, Rondet C, Sarazin M, Heym B, Coignard B, Rossignol L (2016) The economic burden of urinary tract infections in women visiting general practices in France: a cross-sectional survey. BMC Health Serv Res 16:365. https://doi.org/10.1186/ s12913-016-1620-2

8. Sihra N, Goodman A, Zakri R, Sahai A, Malde S (2018) Nonantibiotic prevention and management of recurrent urinary tract infection. Nat Rev Urol 15:750-776. https://doi.org/10.1038/ s41585-018-0106-x

9. Ruppert SM, Hawn TR, Arrigoni A, Wight TN, Bollyky PN (2014) Tissue integrity signals communicated by high-molecular weight hyaluronan and the resolution of inflammation. Immunol Res 58:186-192

10. Mowbray CA, Shams S, Chung G, Stanton A, Aldridge P, Suchenko A, Pickard RS, Ali AS, Hall J (2018) High molecular weight hyaluronic acid: a two-pronged protectant against infection of the urogenital tract? Clin Transl Immunol 7(6):e1021. https:// doi.org/10.1002/cti2.1021

11. Likert R (1932) A technique for the measurement of attitudes. Arch Psychol 22:5-55

12. The British Pain Society (2019) Outcome measures. Retrieved from https://www.britishpainsociety.org/static/uploads/resources/ files/Outcome_Measures_January_2019.pdf. Accessed 11 Oct 2019

13. Andrews JM (2009) BSAC standardized disc susceptibility testing method (version 8). J Antimicrob Chemother 64:454-489

14. Asch DA, Jedrziewski MK, Christakis NA (1997) Response rates to mail surveys published in medical journals. J Clin Epidemiol 50:1129-1136

15. Constantinides C, Manousakas T, Nikolopoulos P, Stanitsas A, Haritopoulos K, Giannopoulos A (2004) Prevention of recurrent bacterial cystitis by intravesical administration of hyaluronic acid: a pilot study. BJU Int 93:1262-1266

16. Raymond I, Vasdev N, Ferguson J, Haskin M, Davis L, Hasan TS (2012) The clinical effectiveness of intravesical sodium hyaluronate (cystistat ${ }^{\circledR}$ ) in patients with interstitial cystitis/painful bladder syndrome and recurrent urinary tract infections. Curr Urol 6:93-98. https://doi.org/10.1159/000343517

17. Vedanayagam M, Brewin J, Briggs K, Ghali Salahia M, Hammadeh MY (2013) The role of hyaluronic acid in the management of uncomplicated recurrent female urinary tract infections: literature review and practical experience. J Clin Urol 6:243-248. https:// doi.org/10.1177/2051415813481027

18. Lipovac M, Kurz C, Reithmayr F, Verhoeven HC, Huber JC, Imhof M (2007) Prevention of recurrent bacterial urinary tract infections by intravesical instillation of hyaluronic acid. Int J Gynaecol Obstet 96:192-195

19. Ciani O, Arendsen E, Romancik M, Lunik R, Costantini E, Di Biase M, Morgia G, Fragalà E, Roman T, Bernat M, Guazzoni G, Tarricone R, Lazzeri M (2016) Intravesical administration of combined hyaluronic acid (HA) and chondroitin sulfate (CS) for the treatment of female recurrent urinary tract infections: a European multicentre nested case-control study. BMJ Open 6:e009669. https://doi.org/10.1136/bmjopen-2015-009669

20. Cicione A, Cantiello F, Ucciero G, Salonia A, Torella M, De Sio M, Autorino R, Carbone A, Romancik M, Tomaskin R, Damiano R (2014) Intravesical treatment with highly-concentrated hyaluronic acid and chondroitin sulphate in patients with recurrent urinary tract infections: results from a multicentre survey. Can Urol Assoc J 8:E721-E727. https://doi.org/10.5489/cuaj.1989

21. Damiano R, Quarto G, Bava I, Ucciero G, De Domenico R, Palumbo MI, Autorino R (2011) Prevention of recurrent urinary tract infections by intravesical administration of hyaluronic acid and chondroitin sulphate: a placebo-controlled randomised trial. Eur Urol 59:645-651. https://doi.org/10.1016/j.eurur o.2010.12.039

22. De Vita D, Giordano S (2012) Effectiveness of intravesical hyaluronic acid/chondroitin sulfate in recurrent bacterial cystitis: a randomized study. Int Urogynecol J 23:1707-1713. https://doi. org/10.1007/s00192-012-1794-z

23. De Vita D, Antell H, Giordano S (2013) Effectiveness of intravesical hyaluronic acid with or without chondroitin sulfate for recurrent bacterial cystitis in adult women: a meta- analysis. Int Urogynecol J 24:545-552

24. Goddard JC, Janssen DA (2018) Intravesical hyaluronic acid and chondroitin sulfate for recurrent urinary tract infections: systematic review and meta-analysis. Int Urogynecol J 29:933-942

Publisher's Note Springer Nature remains neutral with regard to jurisdictional claims in published maps and institutional affiliations. 